\title{
Response of different corn populations to fertigated nitrogen and certain micronutrients in sandy soil
}

\author{
Ahmed Attia ${ }^{1 *}$, Charles Shapiro ${ }^{2}$, Mohamed Gomaa $^{1}$, Ragab Aly ${ }^{1}$, Abd El-Raham Omar $^{1}$ \\ ${ }^{1}$ Agronomy Department, Faculty of Agriculture, Zagazig University, Zagazig, Egypt; *Corresponding Author: ahmedatia@zu.edu.eg \\ ${ }^{2}$ Northeast Research and Extension Center Haskell Agricultural Laboratory, University of Nebraska-Lincoln, Concord, USA.
}

Received 7 November 2010; revised 16 February 2011; accepted 7 March 2011.

\begin{abstract}
A field study was conducted during 2008 and 2009 at El-Khattara farm station, Zagazig University, Sharkyia, Egypt $\left(30^{\circ} 36^{\prime} \mathrm{N}, 3^{\circ} 15^{\prime} \mathrm{E}\right)$ to determine the effect of three $N$ rates $(214,273$, and $333 \mathrm{~kg} \cdot \mathrm{N} \cdot \mathrm{ha}^{-1}$ ), four micronutrients spray treatments (Check, Zn, Mn, and Zn + Mn), and three planting density levels $(4.76,5.71$, and 6.66 plant $\cdot \mathrm{m}^{-2}$ ) on growth and grain yield of corn (Zea mays, L). The soil was sandy (Entisols) and groundwater was used for irrigation. Response to $\mathrm{N}$ was maximized to $214 \mathrm{~kg} \cdot \mathrm{ha}^{-1}$ without a significant effect on most growth traits and grain yield. Agronomic efficiency of $\mathbf{N}$ use for grain yield was negatively related to $\mathrm{N}$ rate $\left(r^{2}=\right.$ 0.49). Application of micronutrients had no effect on most growth and yield characters except a significant increase by $9.5,8.7$, and $9 \%$ in plant weight $\left(\mathrm{g} \cdot\right.$ plant $\left.^{-1}\right)$, biomass yield $\left(\mathrm{kg} \cdot \mathrm{m}^{-2}\right)$, and $\mathrm{N}$ agronomic efficiency for biomass yield, respectively. Growth was decreased by increasing plant density without affecting harvest index, agronomic efficiency, biomass yield, and grain yield. The application of $\mathrm{Zn}$ to the highest maize plant density increased grain yield by $16 \%$ as compared to the check. It is recommended, as predicated by the linear model, that $\mathbf{N}$ fertigation rate should be around $220 \mathrm{~kg} \cdot \mathrm{ha}^{-1}$ with plant density of 6.66 plant $\cdot \mathrm{m}^{-2}$ accompanied by $\mathrm{Zn}$ application for maximum irrigated corn grain yield in sandy soil. Abbreviations: DAS, days after sowing; LA, leaf area; LAI, leaf area index; RPP, relative photosynthetic potential; $\mathrm{HI}$, harvest index; BW, plant weight g.plant ${ }^{-1}$, GYP, grain yield $\mathrm{g} \cdot$ plant $^{-1}, \mathrm{BYM}$, biomass yield $\mathbf{k g} \cdot \mathrm{m}^{-2}$, GYM, grain yield $\mathrm{kg} \cdot \mathrm{m}^{-2}$, NAE, nitrogen agronomic efficiency.
\end{abstract}

Keywords: Fertigation; Micronutrients; Plant Density; Sandy Soil

\section{INTRODUCTION}

The increased demand of maize (Zea mays, L.) by baking and cellulosic biomass industries requires expanding the growing areas to newly reclaimed and sandy soils. Drip irrigation system has become a popular technique to reduce the amount of water and fertilizers applied [1]. Growing corn in rotation with other field and vegetable crops in sandy soil secures a sustainable agriculture to reduce the gap between production and consumption.

Though, sandy soil characterized with low cation exchange capacity and soil organic matter [2] it was proved that fertigation increases fertilizer use efficiency since nutrients are applied to the active root zone which reduces losses of nutrients through leaching or soil fixation [3]. There are mixed literature reviews on corn response to different $\mathrm{N}$ levels. For instance, under similar condition to the present study corn grain yield has been significantly affected by increasing $\mathrm{N}$ rate from 190 to 380 $\mathrm{kg} \mathrm{N} \mathrm{ha}{ }^{-1}$ [4] while plateaued at $180 \mathrm{~kg} \cdot \mathrm{ha}^{-1}$ fertigation rate in another study [5]. Also, a positive response for corn grain yield has been recorded for $\mathrm{N}$ application up to $285 \mathrm{~kg} \mathrm{~N} \mathrm{ha}^{-1}$ [6]. These inconsistencies in results may appear as soil characteristics and other environmental conditions change. As sandy soil has poor water and nutrients retention while the high $\mathrm{N}$ requirement of corn, adequate level of $\mathrm{N}$ must be applied to insure sufficiency. On the other side, there is increased concern about groundwater pollution by nitrate $\left(\mathrm{NO}_{3}-\mathrm{N}\right)$ which attributed to excessive $\mathrm{N}$ fertilizer application [7]. There fore, determining crop response to narrow range of $\mathrm{N}$ levels is so important for more understanding to corn $\mathrm{N}$ requirement for these newly developed areas.

The importance of foliar fertilization with different macro and micronutrients on growth, photosynthetic activity of leaves, and grain yield has been reported by $[8,9]$. Deficiency of $\mathrm{Mn}$ induces growth inhibition, chlorosis and necrosis, early leaf fall, and low reutilization [10]. Some workers reported a significant increase 
in corn growth and yield parameters by micronutrients application. Under sandy soil conditions, ear leaf area, plant height, stem diameter, and HI were increased by the application of $\mathrm{Zn}$ as Zn-EDATA $12 \%$, Mn as Mn-EDATA 12\%, and Fe as Fe-HEEDTA 12\%, as solution spray on maize [11-13]. Also, [14] stated that using microelements raised plants tolerance for water deficit stress conditions which increased the yield. Dry areas of high $\mathrm{pH}$ and low organic matter soils promote $\mathrm{Zn}$ deficiencies in corn $[15,16]$ which makes the need for these micronutrients being more pronounced.

Maize grain is a result of grain yield per plant and number of plant density per unit area. Therefore, studying the effect of plant density on grain yield is necessary as hybrids and technology improve. Modern hybrids have higher radiation use efficiency because of higher LAI at silking which increases their response to high plant densities [17]. Results of previous studies indicated that optimum population of the used cultivar ranged from 5.0 to 5.6 plant $\cdot \mathrm{m}^{-2}$ when grown in clay soils [18]. Across diverse environments, several studies recorded different responses of corn to plant density. For example, corn grain yield was optimized by the combination between plant density of 69000 plant $\cdot \mathrm{ha}^{-1}$ and $250 \mathrm{~kg} \cdot \mathrm{N}$ rate $\mathrm{ha}^{-1}$ [19]. While [20] reported a positive response to plant density ranged from 82000 to 116000 plant $\cdot \mathrm{ha}^{-1}$. Thus, investigating the growth of individual maize plant in sandy soil is important for maximum growth and grain yield especially with the adoption of new irrigation system.
The objectives of this study were to determine the optimum combination of $\mathrm{N}$ rate and plant density with and without $\mathrm{Mn}$ and $\mathrm{Zn}$ application on growth, photosynthetic partitioning parameters, and yield related characteristics in irrigated corn under sandy soil conditions.

\section{MATERIAL AND METHODS}

\subsection{Site Characteristics}

A field experiment was conducted for two growing seasons (2008 and 2009) at the Agricultural Research Stations of the Faculty of Agriculture, Zagazig University in El-Khattara, Sharkyia Governorate, Egypt (30³6' $\mathrm{N}, 32^{\circ} 15^{\prime} \mathrm{E}$ ) and the farm is located at an elevation of 13 $\mathrm{m}$ above the sea level. The average minimum and maximum monthly temperature, precipitation, relative humidity, and wind speed during the summer seasons of 2008 and 2009 are shown in Table 1. According to US soil Taxonomy [21] the sandy high $\mathrm{pH}$ soil is an Entisol with low cation exchange capacity (Table 2).

\subsection{Experimental Design and Treatments}

The experimental design was split-split plot with three replications (Figure 1). The main plot treatments were three nitrogen rates $(\mathrm{N})$ of 214,273 , and $333 \mathrm{~kg} \cdot \mathrm{N} \cdot \mathrm{ha}^{-1}$, the sub plot treatments were four foliar spray micronutrients treatments (S) of $\mathrm{Zn}, \mathrm{Mn}, \mathrm{Zn}+\mathrm{Mn}$, and no $\mathrm{Zn}$ and $\mathrm{Mn}$ applied (check). The sub-sub treatments were three plant densities (D) of 4.76 (low), 5.71 (medium),

Table 1. Average maximum and minimum monthly temperature, precipitation, relative humidity, and wind speed during 2008-2009 summer in El-Khattara, Egypt.

\begin{tabular}{cccccc}
\hline Month & Max Tem. $\left(\mathrm{C}^{\circ}\right)$ & Min Tem. $\left(\mathrm{C}^{\circ}\right)$ & $\begin{array}{c}\text { Percipitation } \\
(\mathrm{mm})\end{array}$ & Relative humidity \% & Wind speed $\left(\mathrm{km} \mathrm{hr}^{-1}\right)$ \\
\hline May & 34.0 & 19.0 & 0.25 & 50 & 14.68 \\
June & 37.0 & 20.4 & 0.10 & 49 & 14.68 \\
July & 38.8 & 22.4 & 0.00 & 56 & 15.75 \\
August & 35.7 & 20.8 & 0.00 & 60 & 13.89 \\
September & 32.0 & 19.4 & 0.00 & 59 & 14.48 \\
\hline
\end{tabular}

Table 2. Mechanical and chemical analysis of the experimental field (0 0.3 m soil depth) in El-Khattara, Sharkyia, Egypt 2008.

\begin{tabular}{|c|c|c|c|}
\hline Properties & & Cation and Anion & \\
\hline Mechanical analysis & & (meq/100 g soil) & \\
\hline Sand & 91.87 & $\mathrm{Ca}^{+2}$ & 0.16 \\
\hline Silt & 6.03 & $\mathrm{Na}^{+2}$ & 0.39 \\
\hline Clay & 2.1 & $\mathrm{Mg}^{+2}$ & 0.18 \\
\hline Soil Texture & Sandy & $\mathrm{K}^{+2}$ & 0.04 \\
\hline Chemical analysis & & (meq/100 g soil) & \\
\hline $\mathrm{N} \mathrm{mg} \mathrm{kg}^{-1}$ & 4.05 & $\mathrm{CO}^{-3}$ & 0.0 \\
\hline $\mathrm{P}$ mg kg-1 & 45.5 & $\mathrm{HCO}^{-3}$ & 0.18 \\
\hline $\mathrm{K} \mathrm{mg} \mathrm{kg}^{-1}$ & 65.5 & $\mathrm{Cl}^{-}$ & 0.22 \\
\hline Mn mg kg-1 & 1.87 & $\mathrm{SO}^{-4}$ & 0.37 \\
\hline Zn mg kg ${ }^{-1}$ & 1.05 & & \\
\hline SOM \% & 0.07 & & \\
\hline $\mathrm{pH}$ & 8.02 & & \\
\hline
\end{tabular}




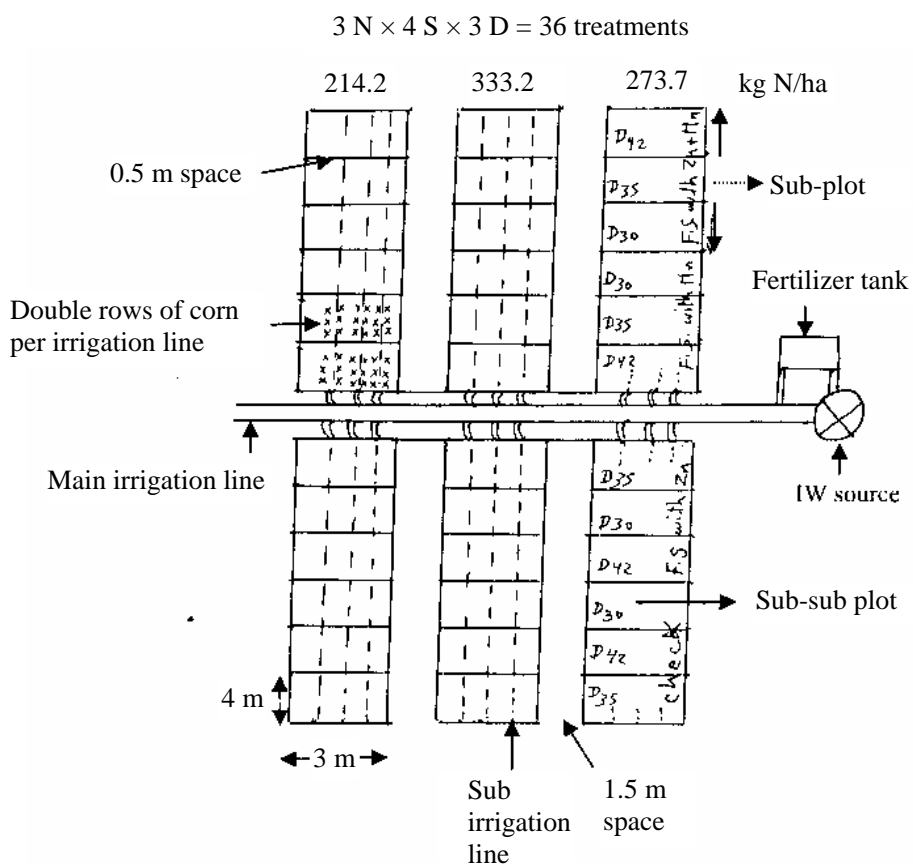

Figure 1. Layout of one replicate showing the study factors and plant distribution in the blocks.

6.66 (high) plant $\cdot \mathrm{m}^{-2}$. Nitrogen was applied as ammonium sulfate (20.5\% N and 24\% S) through the irrigation system in five equal doses from 21 DAS (V3) to 50 DAS (V9) [22].The solution spray of micronutrients treatment was applied in two applications the 1st was at 30 DAS (V4) and the 2nd was at 45 DAS (V8). Tank volume 20 $\mathrm{L}$ water were used for each treatment since $\mathrm{Zn}$ and $\mathrm{Mn}$ sprayed on plant foliage at a rate of $150 \mathrm{~g} \cdot \mathrm{ha}^{-1}$ in the form of EDATA. Plant densities were given by reducing hill spacing form 42, 35, to $30 \mathrm{~cm}$ for low, medium, and high densities, respectively.

The sub-sub plot size was $3 \mathrm{~m}$ by $4 \mathrm{~m}$. All plots were fertilized with $240 \mathrm{~kg} \cdot \mathrm{ha}^{-1}$ calcium superphosphate (15.5\% P) and $129 \mathrm{~kg} \cdot \mathrm{ha}^{-1}$ potassium sulfate $(48 \% \mathrm{~K}$ and $19 \% \mathrm{~S}$ ). The phosphorous and potassium were broadcast applied at seeding around the drip lines.

Each plot has three drip lines space one $m$ apart with drippers spaced $0.35 \mathrm{~m}$ apart within the line and each dripper had a flow rate of $4 \mathrm{~L} \cdot \mathrm{ha}^{-1}$. Irrigation was initiated two days before sowing with a rate of $1.1 \mathrm{~cm} \cdot \mathrm{day}^{-1}$ until tasseling, $2.3 \mathrm{~cm} \cdot \mathrm{day}^{-1}$ from tasseling to R3, and $1.1 \mathrm{~cm} \cdot \mathrm{day}^{-1}$ from R3 to R5. Ground water was pumped from $30 \mathrm{~m}$ soil depth and had an SAR of 11.7 (Table 3).The soil and ground water were analyzed by the central laboratory of the faculty of Agriculture, Zagazig University.

A three way cross corn hybrid (TWC 321 from Gemmeza Research Station, Cairo, Egypt) was manually planted in May 22 on both sides of the drip line with row spacing of one $\mathrm{m}$ apart. The preceding crops were fallow and garlic in the 1st and 2nd seasons, respectively. Three weeks after planting (V3) seedling were thinned to one plant per hill. Weed control consisted of hand weeding throughout the season to control any weeds. Agrinate 90\% SP (Methomy l) insecticide was applied at V3 at a rate of $715 \mathrm{~g} \cdot \mathrm{ha}^{-1}$ for Aphids control.

\subsection{Field and Plant Measurements}

At silking stage (R3) five contiguous plants plot $^{-1}$ were used for measurements; Leaf area plant ${ }^{-1}(\mathrm{LA} /$ plant $\left.\mathrm{dm}^{2}\right)$, such trait was computed as Leaf area $=0.75 \times(\mathrm{L} \times$ $\mathrm{W}$ ) where $\mathrm{L}$ is the blade length $(\mathrm{cm})$ and $\mathrm{W}$ is the maximum width of the blade $(\mathrm{cm})$ [23]. Leaf area index was determined as: leaf area plant ${ }^{-1}\left(\mathrm{dm}^{2}\right) /$ land area plant ${ }^{-1}$ $\left(\mathrm{dm}^{2}\right)$.

Plants were cut at the surface from the two rows on either side of the middle irrigation line on September 25 in both seasons. Ears were manually harvested, shelled, and weighed. Subsamples of grain were oven dried at $60^{\circ} \mathrm{C}$ for adjusting grain yield to $155 \mathrm{~g} \cdot \mathrm{Kg}^{-1}$ water content. Stover sample were air dried for three weeks after harvest at $25.7^{\circ} \mathrm{C}$ mean temperature. Biomass yield was calculated from stover and grain weights. Then the following characters were determined;

Grain yield $\cdot \mathrm{dm}^{-2} \mathrm{LA}\left(\mathrm{g} \cdot \mathrm{dm}^{-2}\right)$, it was determined as: GY at $15.5 \%$ moist $\left(\mathrm{g}\right.$ plant $\left.{ }^{-1}\right) / \mathrm{dm}^{2}$ of LA.

Relative photosynthetic potential (RPP) for: a) grain yield was determined as; $\mathrm{RPP}_{\text {grain }}=\mathrm{Y}_{\text {grain } / \text { lant }} / \mathrm{LAI}$ (g/LAI), b) biomass yield was determined as; $\mathrm{RPP}_{\text {bio }}=$ $\mathrm{RPP}_{\text {bio/plant }} / \mathrm{LAI}$ (g/LAI), this parameter were computed 
Table 3. Ground water analysis in the experimental field site, El-Khattara, Sharkyia, Egypt 2008.

\begin{tabular}{|c|c|c|c|c|c|}
\hline Properties & & Concentration & Properties & & Concentration \\
\hline EC & $\left(\mathrm{dsm}^{-1}\right)$ & 1.53 & $\mathrm{SO}^{-2}$ & (mol./L) & 1.59 \\
\hline $\mathrm{pH}$ & (mol./L) & 8.31 & $\mathrm{Cl}^{-1}$ & (mol./L) & 6.07 \\
\hline $\mathrm{HCO}^{-1}$ & (mol./L) & 7.61 & $\mathrm{Ca}^{+2}$ & (mol./L) & 1.27 \\
\hline $\mathrm{Mg}^{+2}$ & (mol./L) & 1.09 & $\mathrm{Na}^{+2}$ & (mol./L) & 12.87 \\
\hline $\mathrm{K}^{+}$ & (mol./L) & 0.15 & SAR & (mol./L) & 11.73 \\
\hline
\end{tabular}

using the procedure outlined by [24]. Both RPP traits are describing the contribution of leaf area index into biological and grain yield.

Harvest index (HI) was determined as; grain yield $\left(\mathrm{g} \cdot\right.$ plant $\left.^{-1}\right) /$ biomass yield $\left(\mathrm{g} \cdot\right.$ plant $^{-1}$ ). HI determines the total dry matter partitioned into grain yield.

Grain yield $\left(g \cdot\right.$ plant $^{-1}$ ) at $15.5 \%$ moist. Plant weight (g.plant ${ }^{-1}$ ) was calculated from cob, stover, and grain weight per plant. Biomass yield $\left(\mathrm{kg} \cdot \mathrm{m}^{-1}\right)$. Grain yield $\left(\mathrm{kg} \cdot \mathrm{m}^{-1}\right)$. Nitrogen agronomic efficiency (NAE) for: a) Grain yield was determined as: $\mathrm{Kg}$ grain $\mathrm{Kg}^{-1}$ added $\mathrm{N}$,

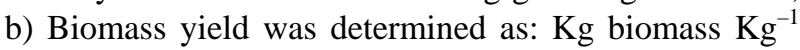
added $\mathrm{N}$.

\subsection{Data Analysis}

Crop performance parameters were analyzed using the SAS PROC GLM procedure to develop the ANOVA for a split-split plot design over years. The PROC MIXED procedure was used to make tests of simple effects [25] with $\mathrm{N}$ rates as the main factor, micronutrients spray as the split factor, and plant density as the split-split factor. Mean separation of treatment effects was measured using Fisher's protested least significant difference (LSD) test. Nitrogen fertilization and plant density were treated as a quantitative variables and solution spray was treated as a qualitative variables. The study factors were treated as fixed effects, and year and replicates were treated as random effects.

\section{RESULTS AND DISCUSSIONS}

\subsection{Growth Parameters}

Linear decrease in LA plant ${ }^{-1}$ (Figure 2(a)) and linear increase in LAI (Figure 2(b)) were recorded by increasing the plant density since the dense planting had the lowest LA plant ${ }^{-1}$ with the highest LAI values. These results could be attributed to the intra-plant competition for the elements essential for production such as light, water and nutrients. This in agreement with the results obtained by [26] who reported that linear increase in LAI with increasing corn population from 60 up to 90 thousand plant $\cdot h a^{-1}$.

Neither $\mathrm{N}$ rate nor applying foliar fertilization influenced LA plant ${ }^{-1}$ and LAI (Table 4) while [27] found a differences in LAI by changing $\mathrm{N}$ rate. As shown in the chemical analysis, the soil has 1.05 and $1.87 \mathrm{mg} \cdot \mathrm{kg}^{-1}$ available $\mathrm{Zn}$ and $\mathrm{Mn}$, respectively. This might account for the insignificant effect of added both microelements on plant LA and LAI observed herein.

According to the combined analysis, the $\mathrm{N} \times \mathrm{D}$ interaction significantly affected LA plant ${ }^{-1}$ (Table 5). Under both low and medium densities, $\mathrm{N}$ rate did not affect LA plant $^{-1}$ but was significantly smaller by $12.7 \%$ for the dense plants fertilized with the lowest nitrogen rate. These results emphasize the importance of considering both nitrogen and planting density effect on the variable. In the pooled data, plant growth factors; $\mathrm{RPP}_{\text {grain }}, \mathrm{RPP}_{\text {dry }}$ mass, and GY dm ${ }^{-2} \mathrm{LA}\left(\mathrm{g} \cdot \mathrm{dm}^{-2}\right)$ were not affected by $\mathrm{N}$ rate and micronutrients application either alone or their interaction (Table 4). Increasing planting density significantly decreased these parameters where, a gradual decrease in both GY dm${ }^{-2} \mathrm{LA}\left(\mathrm{g} \cdot \mathrm{dm}^{-2}\right)$ and RPP traits by increasing the planting density from the low to the high density. The decreases in such potentials could be explained through the increase in harmful effect of shading with the increase in LAI as the population of corn was increased.

The first order interactions were without significant effect on HI over years but HI was affected by YR $\times \mathrm{S}$ interaction (Table 6). The parameter was increased by 6.5\% and $6.6 \%$ due to $\mathrm{Zn}+\mathrm{Mn}$ treatment compared to check in 2008 and 2009, respectively (Figure 3). The high available residual soil $\mathrm{P}$ may be restricted absorption and assimilation of both these micronutrients which has caused unbalanced nutrition. This was more pronounced in the 1st season but planting after garlic in the 2nd season can help in solubility of fixed soil P through its association with Mycorrhizae. These findings sustained those outlined by [28]. Meantime, there was also a significant interaction between $\mathrm{N} \times \mathrm{S}$ since the $\mathrm{HI}$ had a gradual increase with increasing $\mathrm{N}$ rate for plants sprayed with Zn (Table 7).

\subsection{Yield Determination Parameters}

A slight increase was noticed in both BW and GYP due to the application of the $273 \mathrm{~kg} \cdot \mathrm{ha}^{-1} \mathrm{~N}$ rate but not enough to be statistically significant (Table 6). These results are in agreement with the results obtained by [26] where grain $\mathrm{DM}$ of maize response for raising $\mathrm{N}$ rate from 75 to $225 \mathrm{~kg} \cdot \mathrm{N} \cdot \mathrm{ha}^{-1}$ was similar. There was a significant effect for the foliar fertilization on BW (Table 6) 
Table 4. Analysis of variance for the effect of nitrogen (N), foliar fertilization (S), and plant density (D) over two years (YR).

\begin{tabular}{|c|c|c|c|c|c|c|}
\hline Source of variance & $\mathrm{df}$ & LA plant $^{-1}$ & LAI & $\begin{array}{l}\mathrm{GY} \mathrm{dm}{ }^{-2} \mathrm{LA} \\
\left(\mathrm{gm} \cdot \mathrm{dm}^{-2}\right)\end{array}$ & $\begin{array}{c}\mathrm{RPP}_{\text {grain }} \\
\left(\mathrm{g} \cdot \mathrm{LAI}^{-1}\right)\end{array}$ & $\begin{array}{l}\mathrm{RPP}_{\text {dry mass }} \\
\left(\mathrm{g} \cdot \mathrm{LAI}^{-1}\right)\end{array}$ \\
\hline & & & & $\mathrm{P}>F$ & & \\
\hline YR & 1 & 0.006 & 0.109 & 0.015 & 0.012 & 0.005 \\
\hline $\mathrm{N}$ & 2 & 0.531 & 0.740 & 0.393 & 0.417 & 0.203 \\
\hline $\mathrm{YR} \times \mathrm{N}$ & 2 & 0.121 & 0.176 & 0.293 & 0.437 & 0.594 \\
\hline $\mathrm{S}$ & 3 & 0.294 & 0.270 & 0.574 & 0.731 & 0.385 \\
\hline $\mathrm{YR} \times \mathrm{S}$ & 3 & 0.457 & 0.666 & 0.634 & 0.798 & 0.223 \\
\hline $\mathrm{N} \times \mathrm{S}$ & 6 & 0.333 & 0.385 & 0.308 & 0.212 & 0.378 \\
\hline $\mathrm{YR} \times \mathrm{N} \times \mathrm{S}$ & 6 & 0.268 & 0.069 & 0.625 & 0.716 & 0.951 \\
\hline $\mathrm{D}$ & 2 & 0.002 & $<0.0001$ & 0.001 & $<0.0001$ & $<0.0001$ \\
\hline $\mathrm{YR} \times \mathrm{D}$ & 2 & 0.133 & 0.051 & 0.259 & 0.149 & 0.052 \\
\hline $\mathrm{N} \times \mathrm{D}$ & 4 & 0.020 & 0.061 & 0.209 & 0.193 & 0.658 \\
\hline $\mathrm{YR} \times \mathrm{N} \times \mathrm{D}$ & 4 & 0.810 & 0.631 & 0.597 & 0.712 & 0.333 \\
\hline $\mathrm{S} \times \mathrm{D}$ & 6 & 0.755 & 0.970 & 0.067 & 0.205 & 0.340 \\
\hline $\mathrm{YR} \times \mathrm{S} \times \mathrm{D}$ & 6 & 0.931 & 0.398 & 0.841 & 0.413 & 0.321 \\
\hline $\mathrm{N} \times \mathrm{S} \times \mathrm{D}$ & 12 & 0.110 & 0.529 & 0.178 & 0.156 & 0.101 \\
\hline $\mathrm{YR} \times \mathrm{N} \times \mathrm{S} \times \mathrm{D}$ & 12 & 0.495 & 0.132 & 0.720 & 0.657 & 0.963 \\
\hline
\end{tabular}

Table 5. Leaf area plant ${ }^{-1}\left(\mathrm{dm}^{2}\right)$ as affected by nitrogen levels and plant density interaction over years.

\begin{tabular}{cccc}
\hline N levels & Plant density \\
\hline$\left(\mathrm{kg} \mathrm{ha}^{-1}\right)$ & low & medium & high \\
214 & $93.6 \mathrm{Aa}$ & $91.9 \mathrm{Aa}$ & $83.5 \mathrm{Bb}$ \\
274 & $95.7 \mathrm{Aa}$ & $89.3 \mathrm{Ba}$ & $90.9 \mathrm{ABa}$ \\
333 & $90.9 \mathrm{ABa}$ & $94.3 \mathrm{Aa}$ & $86.3 \mathrm{Bab}$ \\
\hline
\end{tabular}

Treatments means are averaged over micronutrients spray. Means in row within $\mathrm{N}$ level followed by the same capital letter are not significantly different at $\mathrm{P}=0.05$ according to Fisher's protested LSD test. Means in column within plant density followed by the same small letter are not significantly different at $\mathrm{P}=0.05$ according to Fisher's LSD test.

Table 6. Analysis of variance for the effect of nitrogen (N), foliar fertilization (S), and plant density (D) over two years.

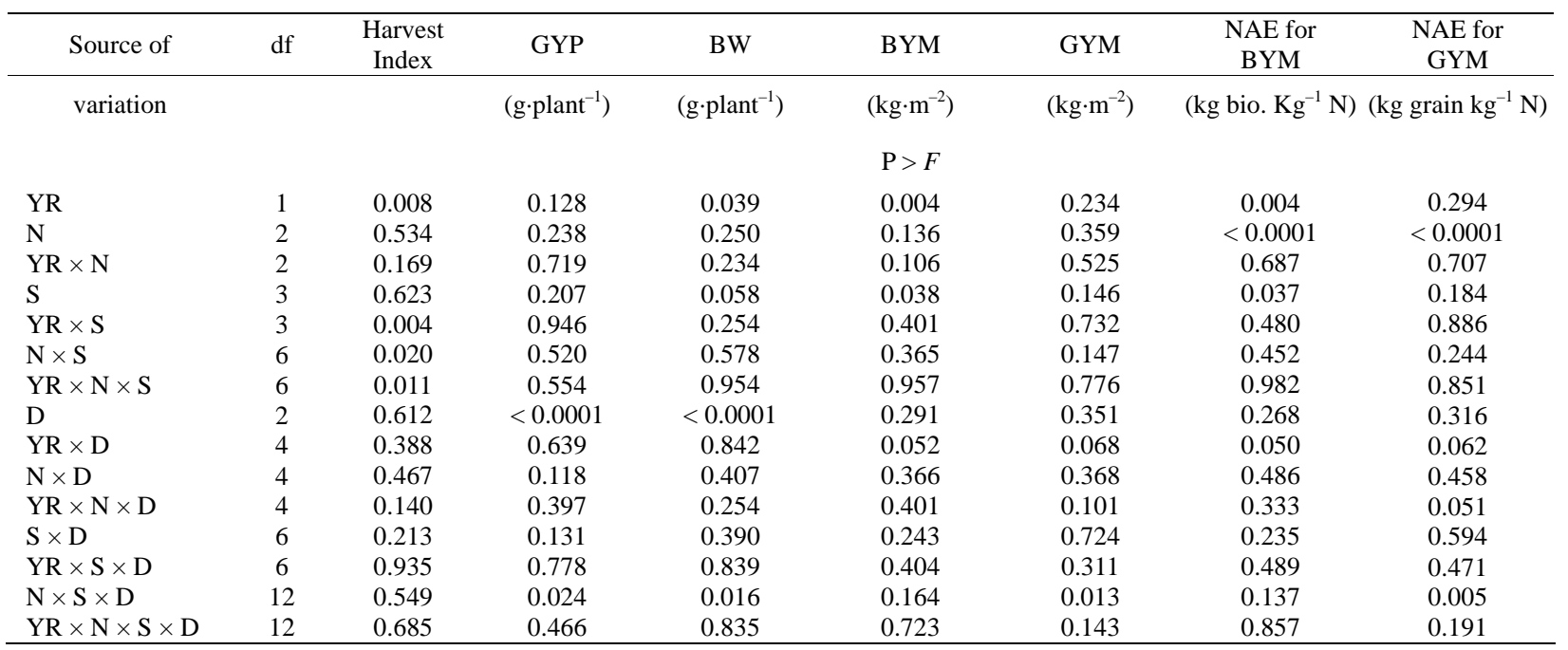

since $\mathrm{Zn}$ treatment was higher by $8.72 \%$ than check treatment. Meanwhile, others have reported significant increase in maize grain yield and its attributes by foliar spray of microelements $[13,29]$. The results of both sea-sons and their combined analysis clearly represented a significant decrease in both BW and GYP regarding varying the plant density (Table 6). It was found a linear decrease in BW as a result of increasing plant density (Figure 4(a)). Whereas, [30] stated that the planting density of 6.6 and 8.3 plants $\cdot \mathrm{m}^{-2}$ recorded 23.5 and 
Combined

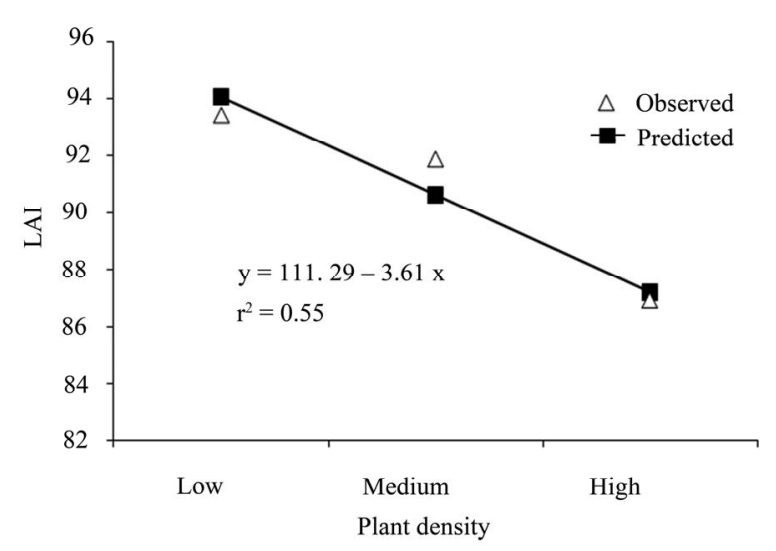

(a)

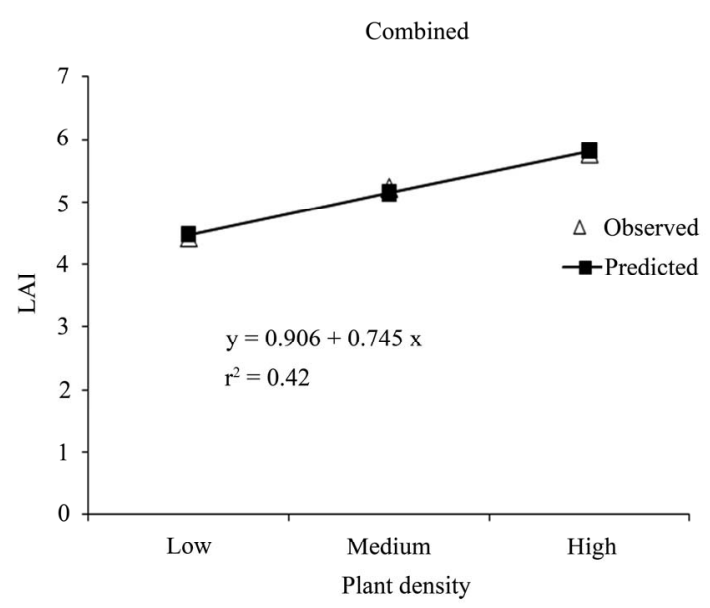

(b)

Figure 2. LA plant ${ }^{-1}\left(\mathrm{dm}^{2}\right)$ (a) as a negative linear function in the pooled data and LAI (b) as a positive linear function in the pooled data.

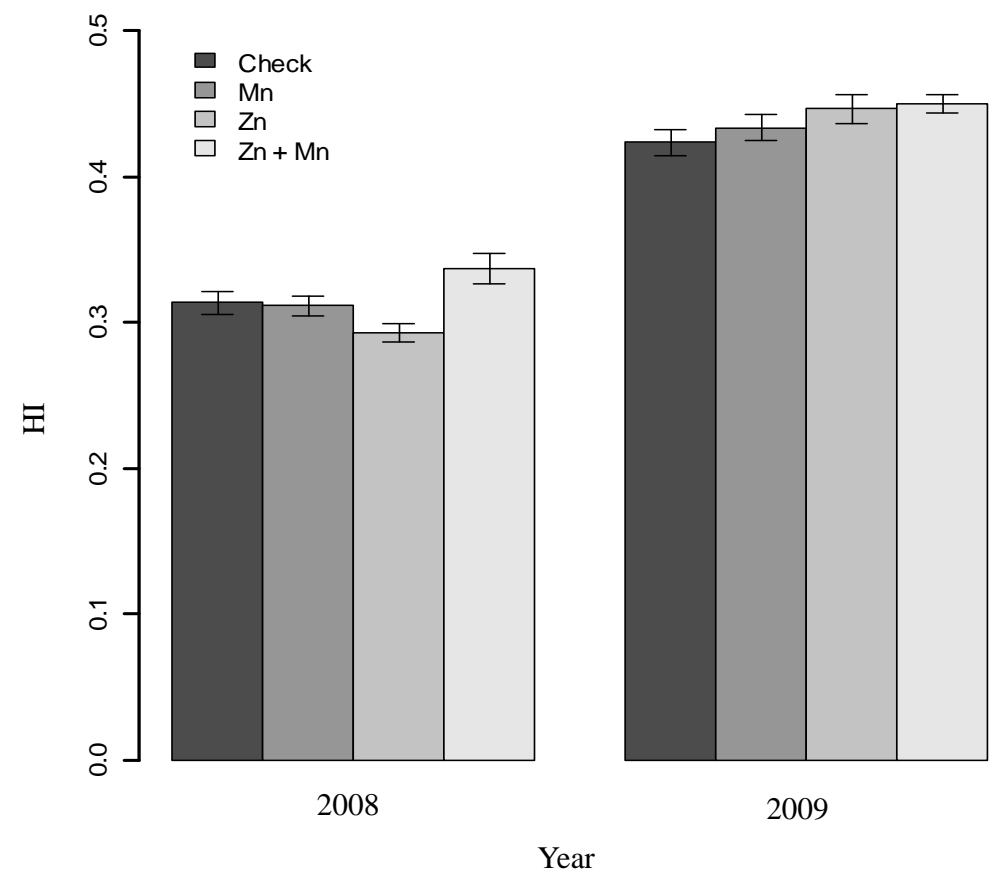

Figure 3. Effect of YR $\times \mathrm{S}$ interaction on harvest index in both seasons. $\mathrm{P}>\mathrm{F}=0.035$ and 0.020 in 2008 and 2009, respectively. Error bars represtent the standard error.

40.0\% higher GY of pop corn compared with 5.55 plants $\mathrm{m}^{-2}$.

It is evident from the results in (Table 6) that none of the first order interactions affected significantly both BW and GYP in both seasons and their combined analysis. These results clearly indicate that the main effect of plant density on both traits masked and dominated any other interacting effects between each two of the factors under study.

Varying $\mathrm{N}$ rate from 214 up to $333 \mathrm{~kg} \cdot \mathrm{ha}^{-1}$ did not af- fect BYM and GYM (Table 6) however, there was a slight increase of $6.83 \%$ and $3.2 \%$ in favor of $273 \mathrm{~kg} \mathrm{~N}$ $\mathrm{ha}^{-1}$ rate compared to $214 \mathrm{~kg} \mathrm{~N} \mathrm{ha}^{-1}$ for BYM and GYM, respectively. Similar findings have been found by [31] where irrigated corn in sandy soils did not response for $\mathrm{N}$ application more than $185 \mathrm{~kg} \cdot \mathrm{ha}^{-1}$ while others reported significant increase in grain yield as a result of raising $\mathrm{N}$ rate from 190 to $380 \mathrm{~kg} \cdot \mathrm{ha}^{-1}$ [4].

Biomass yield $\mathrm{m}^{-2}$ has been affected by foliar fertilization of micronutrients (Table 6) and there was $7.0 \%$ 
increase in GYM due to Zn application compared with the check $(\mathrm{P}>\mathrm{F}, 0.146)$. The beneficial effects of $\mathrm{Zn}$ addition can be achieved partially through its activation of carbonic anhydrase as a catalytic enzyme, consequently $\mathrm{CO}_{2}$ fixation in carbohydrate metabolism. In addition, $\mathrm{Zn}$ deficiency may have a more dramatic effect on the rate of photosynthesis in $C_{4}$ compared with $C_{3}$ plants.

Biomass yield $\mathrm{m}^{-2}$ and GYM were not affected by plant density (Table 6). Though, analysis separates by year showed a significant effect for GYM in 2008 with the following response equation; $\mathrm{y}=-20.864+7.80 \mathrm{x}-$ $0.686 \mathrm{x}^{2}$ this equation indicated that GYM could have been maximized at $1.307 \mathrm{~kg} \cdot \mathrm{m}^{-2}$ with a planting density of 5.71 plants $\cdot \mathrm{m}^{-2}$ (Figure $\left.\mathbf{4 ( b )}\right)$. This possibly could be attributed to the increased pollen to silking intervals and the increased barrenness at the high planting density. These results disagree with [20] since they reported maximum maize grain yield at plant density of 8.2 to 11.6 plants $\cdot \mathrm{m}^{-2}$. There was $\mathrm{YR} \times \mathrm{D}$ interaction effects on BYM showed greater response due to the medium or high plant density in 2008 (Table 8).

There was $\mathrm{N} \times \mathrm{S} \times \mathrm{D}$ interaction effects on grain yield showed differences in $\mathrm{N}$ response depending on spray and densities but, generally there was a negative or constant slope of the line by increasing $\mathrm{N}$ rate (Figure 5). Across $\mathrm{N}$ rates and densities, $\mathrm{Zn}$ treatment produced greater grain yield of $11.6 \mathrm{Mg} \cdot \mathrm{ha}^{-1}$ compared to 10.0 $\mathrm{Mg} \cdot \mathrm{ha}^{-1}$ by check treatment. It is noteworthy that applying $214 \mathrm{~kg} \mathrm{~N}$ ha $^{-1}$ and $\mathrm{Zn}$ to the highest plant density prouced the greatest grain yield of $12.5 \mathrm{Mg} \cdot \mathrm{ha}^{-1}$.These results suggest a beneficial effect of $\mathrm{Zn}$ application on corn grain yield as sandy high $\mathrm{pH}$ soil promotes $\mathrm{Zn}$ deficiency. Zinc has an important role on basic plant life process such as $\mathrm{N}$ metabolism, photosynthesis, carbon anhydrase activity, and resistance to abiotic and biotic stress. The results agree with the finding of [32] since corn grain yield has increased by $18 \%$ as a result of applying 1.0 to $1.5 \mathrm{~kg} \cdot \mathrm{ha}^{-1}$ of $\mathrm{Zn}$. Increasing $\mathrm{N}$ rate did not result in greater grain yield which might be related to nitrogen losses by leaching. Similar results have been reported by [33] where changing $\mathrm{N}$ rate from 128 to 278 $\mathrm{kg} \cdot \mathrm{ha}^{-1}$ did not affect either biomass or grain yield.

The results of both seasons and their combined analysis for NAE for GYM and NAE for BYM indicated that there was a consistent reduction in NAE when $\mathrm{N}$ rate increased from 214 up to $333 \mathrm{~kg} \cdot \mathrm{ha}^{-1}$ (Table 6). Since, as in the pooled data, increasing $\mathrm{N}$ rate from 214 to 273 and to $333 \mathrm{~kg} \cdot \mathrm{ha}^{-1}$ gradually decreased the NAE from 32.03 to 26.78 and to $20.90 \mathrm{~kg} \cdot \mathrm{bio} \cdot \mathrm{kg}^{-1} \mathrm{~N}$ applied and form 11.80 to 9.89 and to $7.67 \mathrm{~kg}$ grain $\mathrm{kg}^{-1} \mathrm{~N}$, in respective order. This agrees with the results obtained by [34] and [35].

The main effect of S significantly affected NAE for BYM (Table 6) where $\mathrm{Zn}$ treatment increased the variable by $9.04 \%$ compared to the check. This matches the results obtained by [36] that NAE has significantly increased by Zn application. Nitrogen agronomic efficiency significantly affected by $\mathrm{YR} \times \mathrm{D}$ interaction but the analysis separates by year did not show a significant effect (Table 8). In addition, $\mathrm{N} \times \mathrm{S} \times \mathrm{D}$ interaction significantly affected NAE for GYM (Table 6) being in-

Table 7. Harvest index as affected by nitrogen and spray interaction in 2009.

\begin{tabular}{ccccc}
\hline N levels & & Micronutrients & Treatment & \\
\hline$\left({\left.\mathrm{kg} \cdot \mathrm{ha}^{-1}\right)}^{2}\right.$ & Check & $\mathrm{Zn}$ & $\mathrm{Mn}$ & $\mathrm{Zn}+\mathrm{Mn}$ \\
273 & $0.401 \mathrm{Aa}$ & $0.381 \mathrm{Cc}$ & $0.402 \mathrm{Aa}$ & $0.388 \mathrm{Bc}$ \\
333 & $0.349 \mathrm{Dc}$ & $0.390 \mathrm{Bb}$ & $0.379 \mathrm{Cc}$ & $0.420 \mathrm{Aa}$ \\
\hline
\end{tabular}

Treatments means are averaged over plant density. Means in row within N levels followed by the same capital letter are not significantly different at $\mathrm{P}=0.05$ according to Fisher's protest LSD test. Means in column within micronutrients treatments followed by the same letter are not significantly different at $\mathrm{P}=0.05$ according to Fisher's protest.

Table 8. Effect of plant density on BYM and NAE for GYM in 2008 and 2009.

\begin{tabular}{ccccc}
\hline Variable & \multicolumn{3}{c}{ Plant density } & F \\
\hline BYM & low & Medium Kg·m ${ }^{-2}$ & high & 0.054 \\
2008 & 3.44 & 3.71 & 3.70 & 0.533 \\
2009 & 2.34 & 2.25 & 2.32 & 0.058 \\
NAE for BYM & & $\mathrm{Kg} \mathrm{m}^{-2}$ & 33.09 & 0.394 \\
2008 & 30.71 & 33.13 & 21.13 & 20.18 \\
2009 & 21.19 & & & 0 \\
\hline
\end{tabular}


Combined

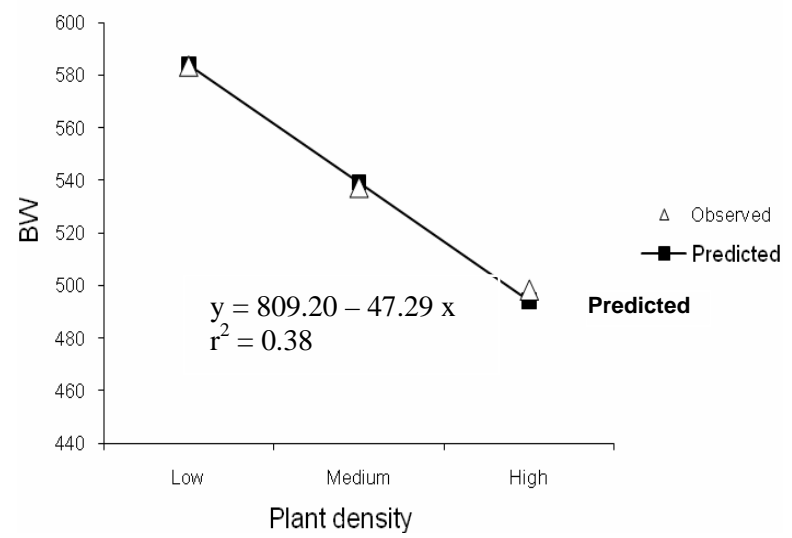

(a)

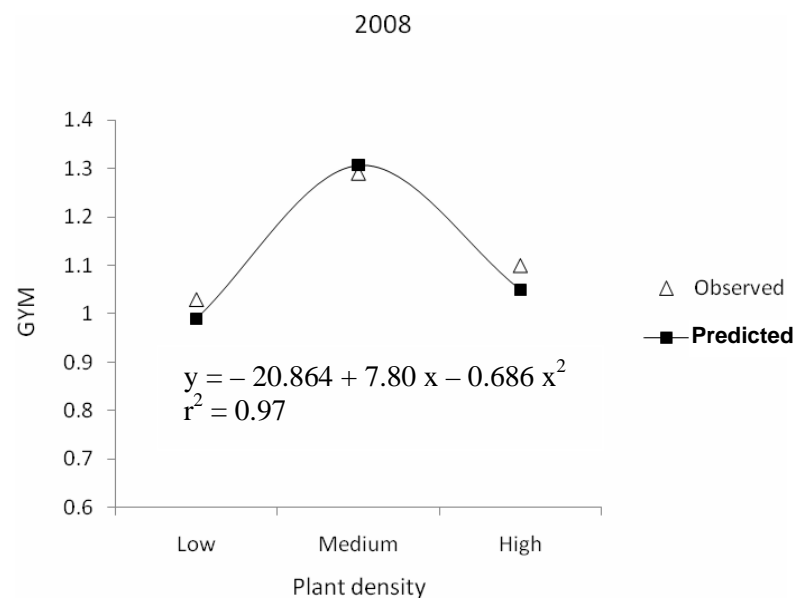

(b)

Figure 4. Plant weight (g.plant ${ }^{-1}$ ) (a) as a negative linear function of plant density in the pooled data and GYM (kg· $\left.\mathrm{m}^{-2}\right)(\mathrm{b})$ as a quadratic function of plant density in 2008.

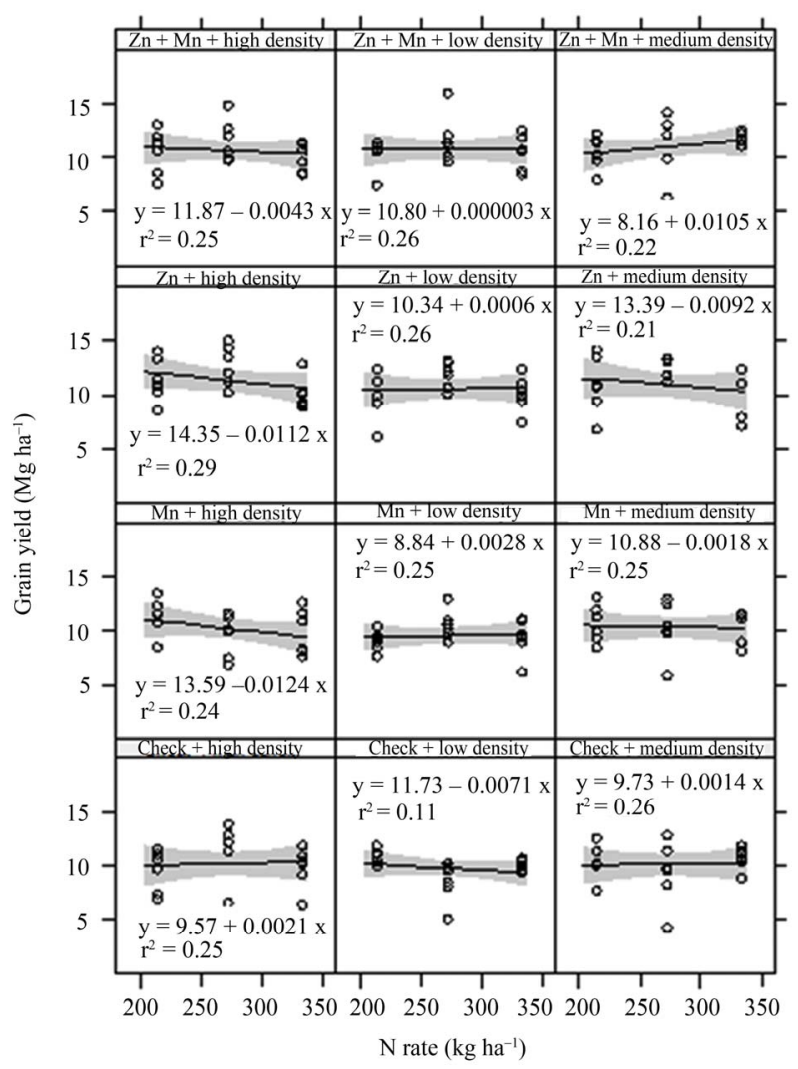

Figure 5. Effect of $\mathrm{N} \times \mathrm{S} \times \mathrm{D}$ interaction on grain yield $\left(\mathrm{Mg} \cdot \mathrm{ha}^{-1}\right)$ over seasons.

Shaded areas are $95 \%$ confidence intervals of the response curve.

favor of applying $214 \mathrm{~kg} \mathrm{~N} \mathrm{ha}^{-1}$ and $\mathrm{Zn}$ with the low density.

\section{CONCLUSIONS}

Expanding corn cultivation through sandy arid soils of Egypt based on drip irrigation system can help in; di- minishing the gap between consumption and production, saving water, and better efficient use for the other agronomic inputs. Corn is so vulnerable to $\mathrm{N}$ deficiency and its grain yield greatly affected by the population. In the meantime, crops grown in sandy soils with high $\mathrm{pH}$ levels suffer from malnutrition with certain micronutrients. 
Accordingly, these three agronomic aspects are of priority for studying.

The results of this study showed a maximum yield response for $\mathrm{N}$ application up to $214 \mathrm{~kg} \cdot \mathrm{ha}^{-1}$ since there was no significant effect due to any extra addition of $\mathrm{N}$ on all the studied traits, except for both NAE traits which gradually reduced as the $\mathrm{N}$ rate increased. Co-application of the lowest fertigated $\mathrm{N}$ rate with $\mathrm{Zn}$ to the highest plant density produced the greatest grain yield of $14.4 \mathrm{Mg} \cdot \mathrm{ha}^{-1}$, along with irrigation frequency as described in the material. Thus, splitting $214 \mathrm{~kg} \mathrm{~N} \mathrm{ha}^{-1}$ considers the best rate and there is no need for further addition of $\mathrm{N}$ under the study conditions especially when it could result in ground water contamination by nitrate $\mathrm{N}$ [37].

Micronutrients spray significantly affected BW, BYM, NAE for BYM, and GYM in favor of Zn treatment without response for the rest of the study characteristics. Most of the study parameters have been affected by increasing the plant density from 4.76 to 6.66 plant $\cdot \mathrm{m}^{-2}$ except biomass and grain yield per $\mathrm{m}^{2}$ which may indicate that a higher plant density might produce more biomass and grain yield per unit area. These results arise that more investigation is required in order to fully understanding the interaction between production factors and optimum plant density for maximizing corn biomass and grain yield under sandy soil conditions.

\section{REFERENCES}

[1] Ayars, J.E., Phene, C.J., Hutmacher, R.B., Davis, K.R., Schoneman, R.A., Vail, S.S. and Mead, R.M. (1999) Subsurface drip irrigation of row crops: A review of 15 years of research at the Water Management Research Laboratory. Agricultural Water Management, 42, 1-27. doi:10.1016/S0378-3774(99)00025-6

[2] Shepherd, M.A. and Bennett, G. (1998) Nutrients leaching losses from a sandy soil in lysimeter. Communications in Soil Science and Plant Analysis, 29, 931-946. doi:10.1080/00103629809369997

[3] Haynes, R.J. (1985) Principles of fertilizers use for trickle irrigated crops. Fert Research, 6, 235-255. doi:10.1007/BF01048798

[4] El-Hendawy, S.E., Hokam, E.M. and Schmidhalter, U. (2008) Drip irrigation frequency: The effects and their interaction with nitrogen fertilization on sandy soil water distribution, maize yield and water use efficiency under Egyptian conditions. Journal of Agronomy and Crop Science, 194, 180-192. doi:10.1111/j.1439-037X.2008.00304.X

[5] Lamm, F.R., Trooien, T.P., Manges, L., Madani, H. and Sunderman, H.D. (2001) Nitrogen fertilization for subsurface drip irrigated corn. Transactions of the ASAE, 44, 530-542.

[6] Halvorson, A.D. and Reule, C.A. (2006). Irrigated corn and soybean response to nitrogen under no-till northern
Colorado. Agronomy Journal, 98, 1367-1374.

[7] Asadi, M.E., Clemente, R.S., Gupta, A.D., Loof, R. and Hansen, G.K. (2002) Impacts of fertigation via sprinkler irrigation on nitrate leaching and corn yield in an acidsulphate soil in Thailand. Agricultural Water Management, 52, 197-213.

[8] Kargbo, C.S. (1985) Effect of plant reproductive stage and rates of foliar fertilizer sprays on corn yield and yield components. Zeitschrift fur Acker und pflanzenbau, 155, 268-273.

[9] Abdul-Galil, A.A., Ghanem, S.A., Zeiton O.A. and Moselhy, M.M. (1990) Effect of planting density and foliar $\mathrm{N}$ fertilization on yield of maize. Proceedings of the 4th Conference Agron, Cairo, 1, 405-417.

[10] Kabata-Pendias, A. and Pendias, H. (1999) Biogeochemistry of Trace Elements. PWN, Warsaw, Poland, 398.

[11] Hefni, E.H.M., El-Hosary, A.A., Salwan, M.I.M. and El-Sabbagh, A. (1993) Effect of soil moisture stress and foliar application of $\mathrm{Zn}$ on some maize varieties. Annals of Agricultural Science, Moshtohor, 31, 1811-1822.

[12] Badr, S.K.A. (1999) Effect of some preceding winter crops and application time and yield components of yellow maize in sandy soil. Minufiya Journal Of Agricultural Research, 24, 895-909.

[13] Bakry, M.A., Soliman, Y.R. and Moussa, S.A. (2009) Importance of micronutrients, organic manure and biofertilizer for improving maize yield and its components grown in desert sandy soils. Research Journal of Agriculture and Biological Sciences, 5, 16-23.

[14] Sajedi, N.A., Ardakani, M.R., Naderi, A., Madani, H. and Boojar, M.M.A. (2009) Response of Maize to Nutrients Foliar Application Under Water Deficit Stress Conditions. Research Journal of Agriculture and Biological Sciences, 4, 242-248. doi:10.3844/ajabssp.2009.242.248

[15] El-Bana, A.Y.A. and Gomaa, M.A. (1994) Response of maize to time of nitrogen application and some microelements under sandy soil conditions. Zagazig Journal of Agriculture Research, 21, 1029-1040

[16] Schulte, E.E. (2004) Understanding plant nutrients, soil and applied Zn. http://learningstore.uwex.edu/Assets/pdf s/A2528.pdf.

[17] Tollenaar, M. and Aguilera, A. (1992) Radiation use efficiency of an old and a new maize hybrid. Agronomy Journal, 84, 536-541.

[18] Greish, M.H. and Yakout, G.M. (2001) Effect of plant population density and nitrogen fertilization on yield and yield components of some white and yellow maize hybrids under drip irrigation system in sandy soil. Proceeding of the International Conference on Plant Nutrition-Food Security and Sustainability of Agro-Ecosystems, Madrid, 810-811.

[19] Al-Kaisi, M.M. and Yin, X. (2003) Effects of nitrogen rate, irrigation rate, and plant population on corn yield and water use efficiency. Agronomy Journal, 95, 14751482.

[20] Porter, P., Hicks, D., Lueschen, W., Ford, J., Warnes, D. and Hoverstad, T. (1997) Corn response to row width and plant population in the northern Corn Belt. Journal of Production Agriculture, 10, 293-300.

[21] Soil Survey Staff (1996) Keys to Soil Taxonomy. 7th Edition, USDA Natural Resource Con-servation Service, Washington DC, 644. 
[22] Ritchie, S.W., Hanway, J.J., Benson, G.O., Herman, J.C. and Lupkes, S.J. (1993) How a corn plant develops. Ext Services Ames, Special report, Iowa State university of Science and Technology Coop, Iowa, 48.

[23] Palamiswamy, K.M. and Gomex, K.A. (1974) Lengthwidth method for estimating leaf area of rice. Agronomy Journal, 66, 430-433.

[24] Vidovic, J. and Pokorny, V. (1973) The effect of different sowing densities and nutrients levels in LAI, production and distribution of dry matter in maize. Biologia planta, 15, 374-382.

[25] Little, R.C., Milliken, G.A., Stroup, W.W. and Wolfinger, R.D. (1996) SAS system for mixed models. SAS Institute, Cary.

[26] Subedi, K.D., Ma, B.L. and Smith, D.L. (2006) Response of leafy and non-leafy maize hybrid to population densities and fertilizer nitrogen levels. Crop Science, 46, 18601869.

[27] Berzsenyi, Z. (2009) Studies on the effect of N fertilization on the growth of maize (Zea mays, L.) hybrids I. Dynamic of drymatter accumulation in whole plants and plant organs. Acta Agronomy Hung, 57, 97-110.

[28] Uribe, E., Martens, C. and Brann, D.E. (1988) Response of corn (Zea mays, L.) to manganese application on Attantic Coastal Plain soils. Plant and Soil, 112, 83-88. doi:10.1007/BF02181756

[29] Yakout, G.M., Greish, G.H. and Atta-All, R.A. (2001) Effect of foliar nutrition with some micronutrients on growth and yield of some white maize cultivars. Egypt Journal of Applied Science, 16, 521-532.

[30] Ashok, K. (2008) Productivity, economics and nitrogen use efficiency of specialty corn (Zea mays, L) as influenced by planting density and nitrogen fertilization. Indian Journal of Agronomy, 53, 306-309.

[31] Gehl, R.J., Schmidt, J.P., Maddux, L.D. and Gordon, W.B. (2005) Corn yield response to nitrogen rate and timing in sandy irrigated soils. Agronomy Journal, 7, 1230-1238.

[32] Potarzycki, J. and Grzebisz, W. (2009) Effect of zinc foliar application on grain yield of maize and its yielding components. Plant and Soil Environment Journal, 55, 519-527.

[33] Tarkalson, D.D. and Payero, J.O. (2008) Comparison of nitrogen fertilization methods and rates for subsurface drip irrigated corn in the semi-arid great plains. Soil and Water Division of ASABE, 51, 1633-1643.

[34] Shapiro, C.A. and Wortmann, C.S. (2006) Corn response to nitrogen rate, row spacing, and plant density in Eastern Nebraska. Agronomy Journal, 98, 529-535.

[35] El-Gizawy, N.K. (2009) Effect of nitrogen rate and plant density on agronomic nitrogen efficiency and maize yields following wheat and faba bean. American Eurasian Journal of agriculture and Environment Science, 5, 378-386.

[36] Osman, A.S., Allam, S.M.M., El-Sherbiny, G.M. and Gebraiel, M.Y. (2001) Influence of nitrogen and micronutrient sources on maize plants. Egypt Journal of Applied Science, 16, 150-160.

[37] Wang, Y.P., Tan, C.C. and Huang, W.B. (1996) Effect of chemical fertilization on the quality of percolation water. Journal of the Chinese Agricultural Chemical Society, 34, 406-416. 